\title{
Sirtuins, aging and diseases
}

\author{
Leonard Guarente \\ From Metabolism, diet and disease \\ Washington, DC, USA. 29-31 May 2012
}

SIR2 and related genes (sirtuins) are NAD-dependent deacetylases that link metabolism, protein acetylation and aging in a variety of species. Sirtuins are also involved in the longevity conferred by dietary or calorie restriction (CR). The mammalian sirtuins SIRT1-7 are involved in changes in stress resistance and metabolism that are triggered by CR, which not only extends life span, but also protects against many diseases of aging. In this talk, I will describe how mamamlian SIRT1 impacts tissue metabolism and diseases by deacetylating nuclear transcription factors that govern key physiological pathways. I will also describe new data from several labs showing that the mitochondrial sirtuin SIRT3 suppresses reactive oxygen species (ROS) in mitochondria and thus links sirtuins, calorie restriction, ROS, mitochondria and aging. The effect of SIRT3 on mitochondrial generated ROS further regulates the key nuclear transcription factor HIF-1 $\alpha$, and may thus govern the metabolic reprogramming (Warburg effect) in cancer. Finally, I will touch upon recent progress in trying to understand the mechanism of action of SIRT1-activating compounds, which are currently in numerous human clinical trials.

Supported by NIA \& Glenn Foundation for Medical Research. LG consults for Sirtris/GSK.

Submit your next manuscript to BioMed Central and take full advantage of:

- Convenient online submission

- Thorough peer review

- No space constraints or color figure charges

- Immediate publication on acceptance

- Inclusion in PubMed, CAS, Scopus and Google Scholar

- Research which is freely available for redistribution

Submit your manuscript at www.biomedcentral.com/submit
C Biomed Central

\section{Biomed Central}

